\title{
Book Reviews and Notices
}

American Indians in U.S. History, by Roger L. Nichols. The Civilization of the American Indian Series, vol. 248. Norman: University of Oklahoma Press, 2003. xxii, 242 pp. Illustrations, maps, chronology, suggested readings, index. $\$ 29.95$ cloth.

Reviewer Donald L. Parman is professor emeritus of history at Purdue University and the author of Indians and the American West in the Twentieth Century (1994).

Author Roger L. Nichols, a distinguished and prolific historian at the University of Arizona, is well qualified to write this book. His previous works include biographies of Henry Atkinson, Stephen Long, and Black Hawk, as well as Indians in the United States and Canada: A Comparative History (1998). Nichols has also edited several anthologies on Indian history and an important historiographical appraisal of American frontier history.

Those familiar with the author's earlier works may be somewhat surprised by American Indians in U.S. History. Instead of a monograph based largely on archival sources, this book, a general overview of American Indian history, relies on secondary sources. Nichols does not employ footnotes or present an extensive bibliography. Even quoted material is not documented. Nichols does, however, provide "Suggested Readings" at the end of chapters for those who might want more detailed information. His intended audience obviously is not fellow specialists but rather general readers who want a basic understanding of American Indian history in a brief treatment.

Nichols's chapters present the story in roughly chronological fashion. He opens with an interesting discussion about the origins of American Indians, with special attention to recent theories that challenge the belief that all American Indians came from Asia to North America via a land bridge. His information seems fresh and up to date. In the following two chapters, Nichols deals with Indians' experiences with European colonial powers from first contacts to the end of the American Revolution. His information suggests that none of the Indians' tactics-war, diplomacy, or cultural renewal-succeeded in protecting their land or political power.

An even more tragic picture emerges from Nichols's discussion of the Indians' fate after the Revolution. Eastern tribes repeatedly found themselves displaced by cession treaties, pressured by white settlers, 
and divided by intratribal factionalism. The War of 1812 largely ended the eastern Indians' ability to resist the federal government and led to their removal to the Trans-Mississippi West in the 1830s and 1840s.

In Chapter 5, "The Struggle for the West, 1840-1890," Nichols narrates the many encounters between western Indians and the white military, the creation of reservations, and post-Civil War reformers' sincere but usually misguided attempts to assimilate Indians into general American society. In the following chapter, Nichols looks at life on reservations in the late nineteenth century and the many adjustments and hardships that Indians confronted.

In a subsequent essay, Nichols takes up the Indian New Deal and the militancy of the early 1970s. Like many previous writers, he views the reforms of the 1930s as generally helpful, but he considers Bureau of Indian Affairs Commissioner John Collier to have been as authoritarian as his predecessors. He also outlines the Red Power phase, including Indians' occupation of Alcatraz and seizure of the Bureau of Indian Affairs offices on the eve of President Richard Nixon's reelection. In his final chapter, "Tradition, Change, and Challenge since 1970," Nichols provides a concise but able discussion of such issues as the anti-Indian backlash, reservation gaming, tribal sovereignty, hunting and fishing rights, energy resources, and repatriation of sacred artifacts.

How well does the author succeed in providing general readers with a basic understanding of the role of Indians in U.S. history? Some may question why some topics were ignored or received little emphasis, but Nichols generally touches on those issues and events that were pivotal. He also avoids the danger of turning his book into a policy study. He sometimes mentions government laws, policies, and treaties, but he is more interested in how they affected Indians. He is careful and objective in his assessments. The writing is clear, concise, and focused. In short, readers who want to know more about Indians and their role in national development will find this book an excellent starting point.

A Projectile Point Guide for the Upper Mississippi River Valley, by Robert F. Boszhardt. A Bur Oak Guide. Iowa City: University of Iowa Press, 2003. xii, 104 pp. Illustrations, bibliography, index. $\$ 14.95$ paper.

Reviewer James M. Collins is an archaeologist at the Office of the State Archaeologist, University of Iowa.

Robert Boszhardt, a productive scholar based at the University of Wisconsin-La Crosse, has provided a guide to the various styles of spear points and arrowheads often found in the areas bordering the Mississippi River between the Quad Cities and Minneapolis-St. Paul. It 
Copyright of Annals of Iowa is the property of State of Iowa, by \& through the State Historical Society of Iowa and its content may not be copied or emailed to multiple sites or posted to a listserv without the copyright holder's express written permission. However, users may print, download, or email articles for individual use. 